\title{
Effects of Temperature and Host on the Generation of Tomato Spotted Wilt Virus Defective Interfering RNAs
}

\author{
Alice K. Inoue-Nagata, Richard Kormelink, Tatsuya Nagata, Elliot W. Kitajima, Rob Goldbach, and Dick Peters
}

First, second, third, fifth, and sixth authors: Department of Virology, Wageningen Agricultural University, Binnenhaven 11, 6709 PD, Wageningen, the Netherlands; and fourth author: NAP/Department of Phytopathology, ESALQ, C.P. 9, 13418-900, Piracicaba, SP, Brazil. Accepted for publication 28 July 1997.

\begin{abstract}
Inoue-Nagata, A. K., Kormelink, R., Nagata, T., Kitajima, E. W., Goldbach, R., and Peters, D. 1997. Effects of temperature and host on the generation of tomato spotted wilt virus defective interfering RNAs. Phytopathology 87:1168-1173.

The generation of defective interfering (DI) RNA molecules of tomato spotted wilt tospovirus (TSWV) was studied by serially passaging inocula from plant to plant under different controlled conditions. DI RNAs were generated at higher rates in plants at $16^{\circ} \mathrm{C}$ than in plants incubated at higher temperatures. Another factor promoting the TSWV DI RNA generation was the use of high virus concentrations in the inocula. The solanaceous species Capsicum annuиm, Datura stramonium, Lycopersi-
\end{abstract}

ABSTRACT con esculentum, Nicotiana benthamiana, and N. rustica supported the generation of DI RNAs, whereas the virus recovered from the inoculated composite species, Emilia sonchifolia, remained free of any DI RNA under all conditions tested. This study resulted in a strategy to maintain DI RNA-free TSWV isolates, as well as in an efficient way to produce a large population of different DI RNA species. A single DI RNA species usually became dominant in an isolate after a few rounds of serial inoculations. The possible mechanisms involved in TSWV DI RNA generation under different inoculation circumstances are discussed.

Additional keywords: Bunyaviridae, host plant species, virus concentration in inoculum.
Defective interfering (DI) RNA molecules, reported for a considerable number of viruses $(2,20,25)$, arise spontaneously by deletions and rearrangements of the viral genome during infection. They are packaged like wild-type RNAs and interfere with the replication of the wild-type virus, i.e., they replicate dependently and preferentially at the expense of the nondefective parental virus (12).

The existence of DI particles was first reported in influenza virus (29) and, subsequently, extensively described in several animal viruses $(2,13,20)$. In plant viruses, the first DI RNA was found in tomato bushy stunt tombusvirus "cherry" strain (TBSV-Ch, also known as petunia asteroid virus [11]). After this report, peculiarities on the conditions of de novo generation of DI RNAs of several viruses were reported, e.g., in the Bromovirus (21), Carmovirus (18), Furovirus (27), and Tombusvirus genera $(3,4,14,24)$.

It is generally accepted that DI RNAs originate as a consequence of serially passaging a virus at high multiplicity of infections through a susceptible host $(25,26)$. A high inoculum concentration was demonstrated to be essential for the generation of DI RNAs of cucumber necrosis tombusvirus (CNV [24]), cymbidium ringspot tombusvirus (CymRSV [4]), and TBSV-Ch (14). At least eight passages were required before the detection of DI RNAs in CNV-inoculated plants (24), whereas DI RNAs could already be detected after the third passage in CymRSV- (4) and TBSV-Chinfected (14) plants. When TBSV-Ch was inoculated in low concentrations, DI RNAs could not be detected after 11 serial passages, suggesting a strong effect of the virus concentration in the inocula on the generation of DI RNAs (14). Factors such as the incubation temperature applied to the inoculated plants, as shown for soilborne wheat mosaic furovirus (6), or the host plant used, when inoculated with CNV (5), were also reported to modulate the rate at which the DI RNAs were generated and accumulated in

Corresponding author: D. Peters; E-mail address: dick.peters@medew.viro.wau.nl

Publication no. P-1997-0929-04R

C) 1997 The American Phytopathological Society the infected plant. It is believed that a complex of factors contribute, either in- or interdependently, to the process of DI RNA formation and accumulation.

DI RNAs of tomato spotted wilt tospovirus (TSWV) were recently detected in serial mechanically inoculated plants using highly concentrated inocula (22). TSWV, the type species of the genus Tospovirus of the family Bunyaviridae, is an enveloped virus containing one negative-sense RNA, large (L) RNA, and two ambisense RNA segments, medium (M) and short (S) RNA, with respective sizes of $8,897,4,821$, and 2,916 bases $(8,9,15)$. The DI RNAs of TSWV, ranging in size from 3.1 to $3.4 \mathrm{~kb}$, were all derived from the L RNA $(22,23)$, which encoded the putative RNA dependent RNA polymerase $(8,28)$. These DI RNAs were consistently associated with disease symptom attenuation in infected plants (22).

In this study, aimed to establish strategies to maintain DI-free TSWV isolates after mechanical inoculation of plants and to produce a large number of distinct DI RNAs, the effect of different inoculation and growing conditions on the generation of DI RNAs was investigated. The analysis demonstrated a striking influence of the temperature, host species, and virus concentration in the inocula on the generation and accumulation of DI RNAs.

\section{MATERIALS AND METHODS}

Virus, plant species, and inoculation procedures. A DI-free stock of the Brazilian wild-type TSWV isolate BR-01 (7) was used in this study to inoculate a first set of three plants. Each plant in this set was used to start a series of plant lines that were successively inoculated with an extract prepared from the last inoculated plant in a line. The first inoculum was prepared by homogenizing systemically infected Nicotiana rustica $\mathrm{L}$. leaves in $0.01 \mathrm{M}$ phosphate buffer, $\mathrm{pH} 7.0$, containing $0.01 \mathrm{M}$ sodium sulfite. After inoculation, the plants were incubated in climate chambers with a daily light regime of $16 \mathrm{~h}$ at a constant temperature of $23^{\circ} \mathrm{C}$, except when the effect of temperature was tested. 
Serial inoculations were made with extracts from systemically infected leaves harvested at a predetermined postinoculation incubation time (Table 1). This period corresponded with the minimum required time for the accumulation of maximal amounts of viral antigen in the infected plants. The virus concentration at this stage was determined by enzyme-linked immunosorbent assay (ELISA), and leaf extract dilutions were adjusted to provide inocula with equal virus concentrations for serial inoculations (Table 1). When a delay of the symptom development occurred during serial passages, the harvesting date was postponed to the second day after the appearance of systemic symptoms. This date usually corresponded with the highest concentration of viral antigens in the plant. Each series consisted of 15 passages.

From every plant, systemically infected leaves were harvested, immediately used as inoculum for the subsequent inoculation, or divided in aliquots and stored at $-70^{\circ} \mathrm{C}$ until further analysis.

Plants to be inoculated were always used in the same developmental stage. Datura stramonium L. and tomato (Lycopersicon esculentum Mill.) cv. Moneymaker were used in the second-leaf stage; N. rustica cv. America and Emilia sonchifolia (L.) DC. ex Wight in the third-leaf stage; sweet pepper (Capsicum annuum L.) cv. Lambada in the fourth-leaf stage; and N. benthamiana Domin. in the fifth-leaf stage.

ELISA. The viral antigen concentration in the systematically infected leaves was estimated by double-antibody sandwich-ELISA using polyclonal antibodies against the nucleocapsid $(\mathrm{N})$ protein. Leaf disks of $5 \mathrm{~mm}$ in diameter were collected from the plants using a one-hole puncher and stored frozen at $-20^{\circ} \mathrm{C}$. Before plating, each disk was crushed in $0.01 \mathrm{M}$ potassium phosphate buffer, pH 7.2, containing $0.14 \mathrm{M} \mathrm{NaCl}$ and $0.05 \%$ Tween-20 (PBS-T) in a dilution of $1 \mathrm{mg}$ of leaf/ml of PBS-T. This high dilution was used to avoid saturation of the antigen-antibody reaction. Each sample was tested in duplicate using $100 \mu \mathrm{l}$ of extract per well.

Northern blotting. To analyze the presence of L RNA-specific RNA species, total RNA extracts of systemically infected leaves were tested by Northern blot hybridization. The analysis was performed after the fifth, tenth, and fifteenth passage. These extracts were prepared using the sodium dodecyl sulfate-sodium acetate method (10), except for $N$. benthamiana, for which a method with guanidium hydrochloride (19) was used. The RNA from $0.1 \mathrm{~g}$ of systemically infected leaf material was finally resuspended in $25 \mu \mathrm{l}$ of $\mathrm{H}_{2} \mathrm{O}$. A 5-ml aliquot of each extract was denatured with methylmercuric hydroxide (1), subjected to electrophoresis in a $1 \%$ agarose gel using a borate buffer ( $50 \mathrm{mM}$ boric acid, $5 \mathrm{mM}$ sodium borate, and $10 \mathrm{mM}$ sodium sulfate without addition of methylmercuric hydroxide), $\mathrm{pH} 8.1$, and transferred onto a nylon membrane (Genescreen NEF 972; DuPont NEN, Dordrecht, the Netherlands). Northern blot hybridization was performed with a mixture of two distinct double-stranded-DNA probes that were ${ }^{32} \mathrm{P}$-labeled by random priming. One probe was specific to the $5^{\prime}$ termini (nucleotide positions 1 to 1,178 ) and the other to the $3^{\prime}$ termini (nucleotide positions 7,749 to 8,897 ) of the reported viral complementary (vc) strand of TSWV L RNA (8).

Reverse transcription and polymerase chain reaction (PCR). First-strand L RNA-specific cDNA was synthesized from total RNA extracts using the primer pDH001 (CCCGGATCCTCGAGAGCAATCAGGTAACA, identical to the first 17 nucleotides of the vc strand of TSWV L RNA [8]). Prior to PCR amplification and subsequent cloning, cDNA was treated with 1 unit of RNAse $\mathrm{H}$ (Gibco BRL, Gaithersburg, MD) at $37^{\circ} \mathrm{C}$ for $20 \mathrm{~min}$. PCR amplification was performed according to manufacturer procedures using Taq Extender PCR Additive (Stratagene Inc., La Jolla, CA) using pDH001 and pDH002 (CCCGTCGACTAATACGACTCACTATAGAGCAATCAGGTACAA, complementary to nucleotides 8,880 to 8,897 of the vc strand of TSWV L RNA [8]). Each of the 40 cycles of PCR amplification consisted of $30 \mathrm{~s}$ of denaturation at $94^{\circ} \mathrm{C}, 1 \mathrm{~min}$ of annealing at $52^{\circ} \mathrm{C}$, and $4 \mathrm{~min}$ of extension at $72^{\circ} \mathrm{C}$.
PCR products were subjected to electrophoresis in $1 \%$ agarose gel containing ethidium bromide.

\section{RESULTS}

Determination of incubation time and dilution rate for serial inoculations. To study the factors involved in the generation of DI RNAs, total control of inoculation conditions was required. To provide more accuracy during serial inoculations, the infection development was studied by monitoring the incubation time and establishing the dilution of leaf extracts to be used (Table 1). Leaf disks were collected daily after inoculation and tested by ELISA using antibodies against $\mathrm{N}$ protein. Accumulation of virus was invariably sigmoidal with time. After a lag period, the virus accumulated at a fast rate and reached a plateau that remained stable throughout the evaluation time of 32 days (data not shown).

The minimum time required for accumulation of the maximal amount of viral protein varied with the conditions applied (Table 1). The ELISA values recorded after the incubation period are shown in Table 1 as the mean value of five replicates. The small variation of the ELISA values found in the five solanaceous hosts indicated the presence of similar virus concentrations in the leaves under all test conditions. The only exception was the E. sonchifolia plants, which had an approximately two times lower virus concentration (Table 1). Based on these results, a plant extract dilution of five times was chosen to inoculate the solanaceous hosts, and two times when E. sonchifolia was tested. This provided inocula with approximately equal virus concentrations in the successive serial passages (Table 1).

Effect of host plant on the generation of DI RNAs. To investigate whether different systemic host plant species affect the formation and accumulation of DI RNAs of TSWV, the solanaceous species $C$. annuum, D. stramonium, L. esculentum, $N$. benthamiana,

TABLE 1. Accumulation of virus antigen in systemically infected hosts after applying different inoculation and growing conditions

\begin{tabular}{|c|c|c|c|}
\hline Tested condition & Incubation $^{\mathrm{a}}$ & ELISA $^{b}$ & Dilution $^{\mathrm{c}}$ \\
\hline \multicolumn{4}{|l|}{$\overline{\text { Host }^{\mathrm{d}}}$} \\
\hline Nicotiana rustica & 8 & $0.33 \pm 0.05$ & 5 \\
\hline Tomato & 9 & $0.25 \pm 0.04$ & 5 \\
\hline Sweet pepper & 9 & $0.30 \pm 0.01$ & 5 \\
\hline Nicotiana benthamiana & 7 & $0.23 \pm 0.02$ & 5 \\
\hline Datura stramonium & 8 & $0.30 \pm 0.02$ & 5 \\
\hline Emilia sonchifolia & 8 & $0.14 \pm 0.02$ & 2 \\
\hline \multicolumn{4}{|l|}{ Temperature $e^{e, f}$} \\
\hline $16^{\circ} \mathrm{C}$ & 12 & $0.40 \pm 0.04$ & 5 \\
\hline $30^{\circ} \mathrm{C}$ & 7 & $0.28 \pm 0.01$ & 5 \\
\hline \multicolumn{4}{|l|}{ Dilution $^{\mathrm{e}, \mathrm{g}}$} \\
\hline 50 & 8 & $0.27 \pm 0.02$ & $\ldots$ \\
\hline 1,000 & 9 & $0.25 \pm 0.02$ & $\ldots$ \\
\hline \multicolumn{4}{|l|}{ Incubation time $\mathrm{e}^{\mathrm{e}, \mathrm{h}}$} \\
\hline 16 days & t & $0.33 \pm 0.04$ & 5 \\
\hline 32 days & $\ldots$ & $0.30 \pm 0.05$ & 5 \\
\hline
\end{tabular}

${ }^{a}$ Incubation time (days) required for maximum accumulation of nucleocapsid protein.

${ }^{b}$ Mean enzyme-linked immunosorbent assay (ELISA) values $(405 \mathrm{~nm})$ of five replicates obtained from extracts of leaves collected at the incubation time ${ }^{\mathrm{a}}$. Standard error deviations are indicated.

${ }^{c}$ Dilution of leaf extract employed for serial inoculations (wt/vol).

${ }^{d}$ Plants were inoculated with five times diluted leaf extracts and incubated at $23^{\circ} \mathrm{C}$.

${ }^{\text {e }} N$. rustica plants, inoculated with five times diluted leaf extracts and incubated for 8 days at $23^{\circ} \mathrm{C}$, were part of these comparative studies.

${ }^{\mathrm{f}}$ Incubation temperature of $N$. rustica plants inoculated with five times diluted leaf extracts.

${ }^{g}$ Dilution of leaf extracts (wt/vol) before inoculating $N$. rustica plants and incubating at $23^{\circ} \mathrm{C}$.

${ }^{\text {h }}$ Age of the infection in $N$. rustica plants inoculated with five times diluted leaf extracts and incubated at $23^{\circ} \mathrm{C}$. 
$N$. rustica, and the composite species E. sonchifolia were inoculated with TSWV during serial passages.

Total RNA extracts from infected leaves collected after the fifth passage were analyzed by hybridization using L RNA-specific probes (Fig. 1A). In addition to the full-length L RNA, smaller RNA molecules could clearly be detected in one tomato line (To2 ), in two sweet pepper lines (Pe-1 and -2), and in two D. stramonium lines (Da-1 and -2). They were not detected in any N. rustica $\left(23^{\circ} \mathrm{C}-5\right), N$. benthamiana (Be), and E. sonchifolia (E) plants.

These smaller RNAs did not represent breakdown products of the L RNA, since they were PCR-amplified using primers specific to both genomic ends of the L RNA. Total RNA extracts from plants infected with TSWV DI RNAs were reverse-transcribed and subjected to PCR amplification. Electrophoresis of these PCR products revealed DNA fragments with the expected sizes, as estimated on Northern blots (Fig. 2, DI Pe-1, Pe-2, and Da-7). These defective RNA molecules will be further referred to as DI RNAs.

In addition to the DI RNAs found in the fifth passage, after the tenth passage (Fig. 1B), DI RNAs were detected in two N. rustica lines $\left(23^{\circ} \mathrm{C}-5-2\right.$ and -3$)$, in one $N$. benthamiana line (Be-3), and in one sweet pepper line (Pe-3). Once more, DI RNA molecules were not detected in any of the E. sonchifolia lines analyzed.

DI RNA molecules were observed in all the solanaceous hosts analyzed after the fifteenth passage (Fig. 1C), except for one $N$. rustica $\left(23^{\circ} \mathrm{C}-5-1\right)$, one tomato (To- 1$)$, and one $N$. benthamiana line (Be-2). No DI RNAs were detected in any of the three $E$. sonchifolia lines.

The first DI RNA was detected in a D. stramonium line (Da-1) during the third passage (data not shown), whereas, in most other cases, DI RNAs were found during the fifth to fifteenth passage (Fig. 1). Analysis of the migration rate of DI RNAs in Northern blot hybridization showed that DI RNAs, once detected, were preserved in subsequent passages. In three lines, however, the DI RNAs originally found were clearly replaced by new, larger molecules during subsequent passages. This phenomenon was observed in line 2 of $N$. rustica (Fig. $1 \mathrm{~B}$ and $\mathrm{C}, 23^{\circ} \mathrm{C}-5-2$ ), line 3 of sweet pepper (Fig. 1B and $\mathrm{C}, \mathrm{Pe}-3$ ), and line 3 of $N$. benthamiana (Fig. 1B and C, Be-3).

Doublets of full-length L RNA or DI RNA bands (Fig. 1A, To and $\mathrm{Pe}$ ) were observed in Northern blot analysis. They could not be observed in all RNA preparations, although identical protocols for RNA extraction and electrophoresis were used. Using strandspecific riboprobes, double L and DI RNAs bands were shown to consist of viral and ve strands of TSWV (data not shown). These results confirmed earlier reports of differential strand migration of TSWV L and S RNAs (16).

Effect of inoculum concentration on the generation of DI RNAs. To analyze the effect of virus concentrations in the inocula on the generation of DI RNAs, plants of $N$. rustica plants were inoculated with a 5, 50, or 1,000 times diluted extract of wild-type TSWV-infected plants and, subsequently, serially passaged.

DI RNAs could not be detected in any of the lines after the fifth passage, when total RNA was analyzed by Northern blot hybridization (Fig. 1A, $23^{\circ} \mathrm{C}-5,-50$, and -1,000). However, after the tenth passage (Fig. 1B), DI RNAs were found in two out of three lines inoculated with a five times diluted extract $\left(23^{\circ} \mathrm{C}-5-2\right.$ and -3$)$ and in one out of three lines with the 50 times diluted extract $\left(23^{\circ} \mathrm{C}-50-1\right)$.

After the fifteenth passage (Fig. 1C), none of the lines inoculated with 1,000 times diluted extract contained DI RNAs, whereas they were present in two lines inoculated with five times diluted $\left(23^{\circ} \mathrm{C}-5-2\right.$ and -3$)$ and in all three lines with 50 times diluted extracts. Our results supported the general view $(25,26)$ that the use of high virus concentration in the inocula promotes DI RNA generation.

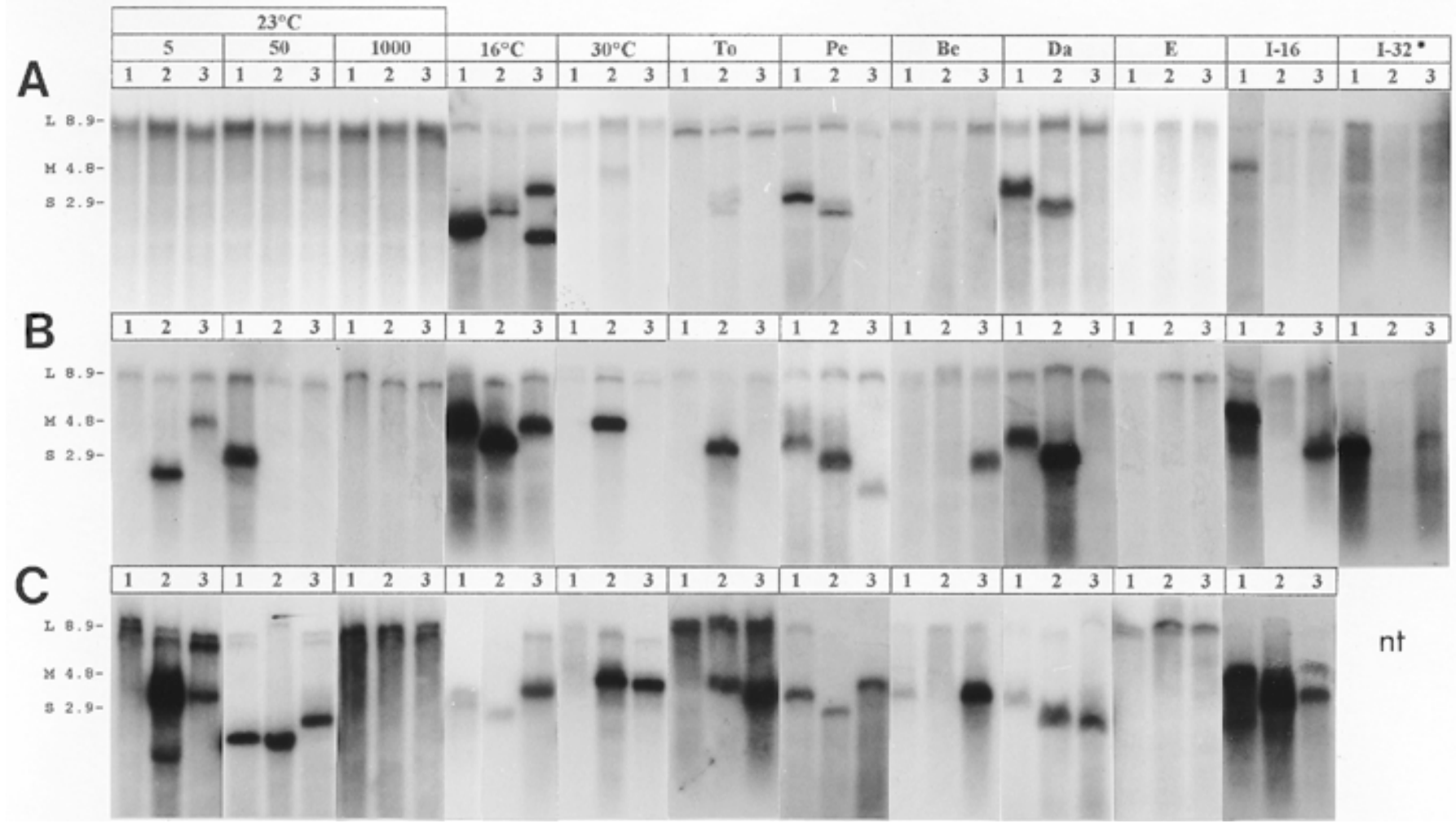

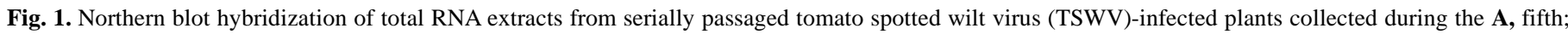

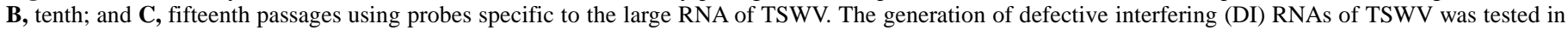

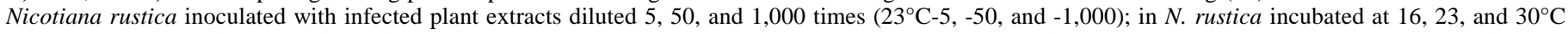

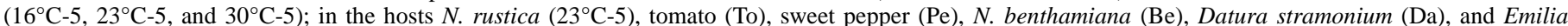

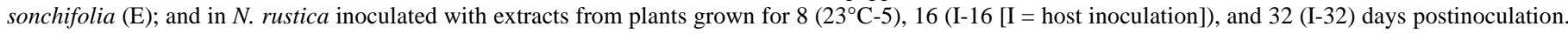

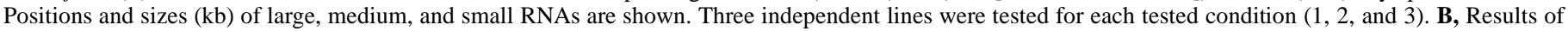
Northern blot hybridization on the ninth passage for I-32 (asterisk). nt $=$ not tested. 
Effect of temperature on the generation of DI RNAs. The influence of temperature on the generation of DI RNA molecules was also analyzed. $N$. rustica plants were serially inoculated with a five times diluted infected plant extract and incubated at 16, 23, or $30^{\circ} \mathrm{C}$. Total RNA was extracted from plants after the fifth passage (Fig. 1A) and subjected to Northern blot analysis. The results showed that DI RNAs were generated in all three lines kept at $16^{\circ} \mathrm{C}\left(16^{\circ} \mathrm{C}\right)$, but in none of the lines kept at $23^{\circ} \mathrm{C}\left(23^{\circ} \mathrm{C}-5\right)$ and only in one line kept at $30^{\circ} \mathrm{C}\left(30^{\circ} \mathrm{C}-2\right)$. After the fifteenth passage, DI RNAs were found in two out of three lines incubated at $23^{\circ} \mathrm{C}$ (Fig. $1 \mathrm{C}, 23^{\circ} \mathrm{C}-5-2$ and -3 ) and $30^{\circ} \mathrm{C}$ (Fig. $1 \mathrm{C}, 30^{\circ} \mathrm{C}-2$ and -3 ).

Northern blot analysis of all individual passages demonstrated that the DI RNAs could already be detected in the second or third passage in the lines incubated at $16^{\circ} \mathrm{C}$ (Fig. 3), whereas the first DI RNA was detected in the fifth passage in a line kept at $30^{\circ} \mathrm{C}$ (data not shown). These results indicated that lower temperatures had a stimulating effect on the generation or accumulation of TSWV DI RNAs.

To confirm the importance of low temperature incubation on DI RNA formation and accumulation, their effect was studied in another series of three lines for only five passages. Northern blot analysis of the plants (Fig. 4) showed that all lines kept at 16 and $23^{\circ} \mathrm{C}\left(16^{\circ} \mathrm{C}-5\right.$ and $\left.23^{\circ} \mathrm{C}-5\right)$ contained DI RNAs, while a DI RNA was present in only one of the three lines kept at $30^{\circ} \mathrm{C}\left(30^{\circ} \mathrm{C}-1\right)$. Analysis of the first to fourth passage plants incubated at $16^{\circ} \mathrm{C}$ revealed that the first DI RNAs could already be detected in the second or third passage, whereas they appeared after the third passage in the 23 or $30^{\circ} \mathrm{C}$ lines (data not shown). These results strongly suggested that low temperature consistently favors the generation and accumulation of TSWV DI RNAs in N. rustica plants.

Effect of inoculum concentration on the generation of DI RNAs in plants incubated at $16^{\circ} \mathrm{C}$. The results presented showed that low temperature and high virus concentrations in the inocula accelerated the generation of DI RNAs in serially TSWV-inoculated plants. To study whether low temperatures can further influence the rate of the formation of DI RNAs when plants are inoculated with different virus concentrations in inocula, $N$. rustica plants were inoculated with 5, 50, or 1,000 times diluted extracts from infected plants, incubated at $16^{\circ} \mathrm{C}$, and serially passaged five times. After these passages, no distinct effect of the different virus concentrations could be observed on the generation of DI RNAs (Fig. 4, $16^{\circ} \mathrm{C}-5,-50$, and $\left.-1,000\right)$. DI RNAs were generated in all three lines incubated at $16^{\circ} \mathrm{C}$, independently of the virus concentration in the inocula used. More detailed analysis demonstrated that the first DI RNAs could be detected after the first passage and the last ones in the fourth passage (data not shown).

A

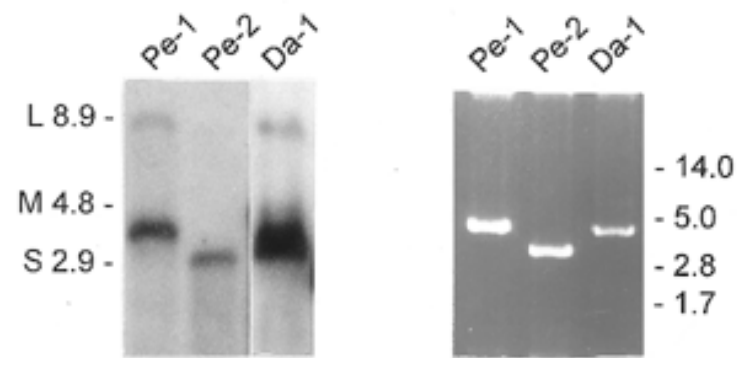

Fig. 2. A, Northern blot hybridization of total RNA extracts after the fifteenth passage of sweet pepper lines 1 and 2 (Pe-1 and Pe-2) and Datura stramonium line 1 (Da-1). Hybridization was performed using probes specific to large RNA. Positions and sizes (kb) of large, medium, and small RNAs are shown. B, Electrophoresis of polymerase chain reaction-amplified DNA fragments from Pe-1, Pe-2, and Da-1. DNA size marker is indicated on the right $(\mathrm{kb})$
The generation of DI RNAs in $E$. sonchifolia at 16,23 , or $3^{\circ} \mathbf{C}$. Since no DI RNAs were detected in E. sonchifolia plants incubated at $23^{\circ} \mathrm{C}$, it was questioned whether other incubation temperatures could promote the generation of DI RNAs in plants of this species. The occurrence of DI RNAs was studied in serially inoculated E. sonchifolia plants incubated at 16,23 , or $30^{\circ} \mathrm{C}$ and passaged five times using two times diluted infected $E$. sonchifolia plant extracts. Northern blot analysis of samples collected after the fifth passage revealed that DI RNAs were completely absent in these lines (data not shown).

Effect of infection age on the generation of DI RNAs. To determine whether the length of infection would affect the generation of DI RNAs, inocula were prepared from $N$. rustica plants infected for 8,16 , or 32 days. Up to 15 serial passages were performed for the lines inoculated in 8- and 16-day intervals, whereas a total of nine passages were performed for plants infected for 32 days. After the fifth passage, no DI RNAs were detected in any of the three lines serially passaged at 8 -day intervals (Fig. $1 \mathrm{~A}, 23^{\circ} \mathrm{C}-5$ ), while DI RNAs were observed in two of the three lines after 10 and 15 passages (Fig. 1B and $\mathrm{C}, 23^{\circ} \mathrm{C}-5-2$ and -3 ). In the treatment in which the inoculum was prepared 16 days after inoculation, DI RNAs were observed in one line after the fifth passage (Fig. 1A, inoculation [I] 16-1), in two lines after the tenth passage (Fig. 1B, I16-1 and -3), and finally in all three lines after the fifteenth passage (Fig. 1C). In lines inoculated with leaf extracts from plants incubated for 32 days, no DI RNAs were seen after the fifth passage (Fig. 1A, I-32), but two lines revealed the presence of DI RNAs in the total RNA extracts after the ninth passage (Fig. 1B, I-32-1). These results showed that the age of the infection in

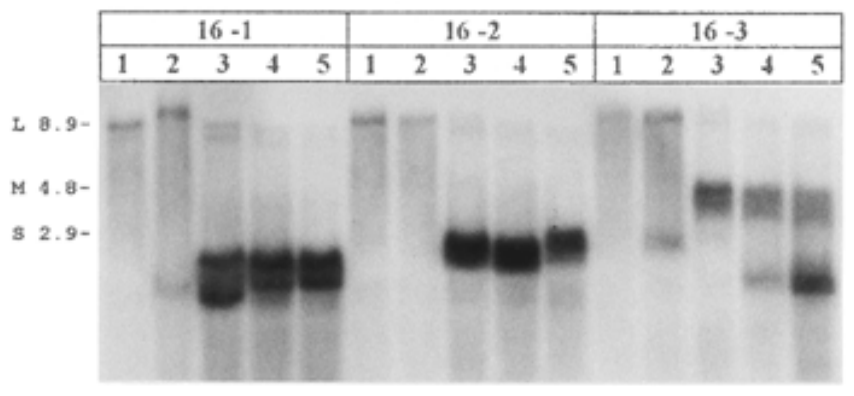

Fig. 3. Hybridization of total RNA extracts from Nicotiana rustica plants in which tomato spotted wilt virus (TSWV) was passaged one to five times (lanes 1 to 5$)$ in three lines kept at $16^{\circ} \mathrm{C}(16-1,16-2$, and 16-3) using large RNA-specific probes. Positions and sizes $(\mathrm{kb})$ of the large, medium, and small RNA are shown. Defective interfering RNAs were detected at passage 2 in line 16-1 and 16-3, and at passage 3 in line 16-2.

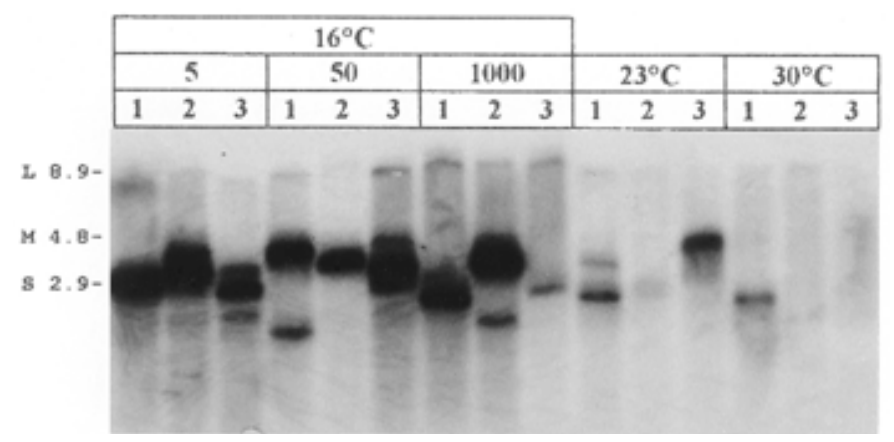

Fig. 4. Northern blot hybridization of total RNA extracts prepared from plants after the fifth passage using probes specific to the large RNA. Nicotiana rustica plants were inoculated with five times diluted extracts from infected plants and incubated at different temperatures $\left(16^{\circ} \mathrm{C}-5,23^{\circ} \mathrm{C}-5\right.$, and $\left.30^{\circ} \mathrm{C}-5\right)$, or inoculated with different inoculum concentrations $\left(16^{\circ} \mathrm{C}-5,-50\right.$, and $-1,000)$ and incubated at the temperature of $16^{\circ} \mathrm{C}$. Positions and sizes (kb) of large, medium, and small RNAs are shown. Three independent lines were tested for each tested condition $(1,2$, and 3$)$. 
plants from which the inocula were derived had no significant stimulating effect on favoring the generation of DI RNA in $N$. rustica plants.

\section{DISCUSSION}

In this report, the effects of hosts, virus concentrations in inocula, incubation temperatures, and ages of the infection in the inoculated plants were examined for their roles in the generation and accumulation of TSWV DI RNA molecules. A delay in symptom expression and the appearance of milder symptoms were usually associated with the emergence of DI RNAs in the TSWV isolate used, although the level at which the symptoms were attenuated varied with the DI RNA (data not shown). The symptom-attenuating property, the amplification by PCR using primers directed to both ends of the L RNA genome, and the large amount of smaller RNA molecules produced compared with the amount of L RNA indicated that the isolates consisted of genuine DI RNA molecules (12) of TSWV. A single DI RNA species usually dominated an isolate after a few rounds of serial inoculations. This was also observed after simultaneous inoculation of distinct DI RNAs in a single plant (data not shown).

DI RNAs could be readily detected after serial passages of TSWV, particularly in plants incubated at $16^{\circ} \mathrm{C}$. DI RNA molecules could be detected as early as in the first passage, although they were usually found after the second passage. The more frequent generation of DI RNAs at $16^{\circ} \mathrm{C}$ could be due to changes in the RNA (or ribonucleoprotein complex) configurations leading to a lower fidelity of replication. Furthermore, the viral polymerase may perform suboptimally at lower temperatures, resulting in the formation of aberrant replication products. Most of the hitherto suggested models for the genesis of DI RNAs involve transcription or replication errors during viral RNA synthesis $(17,20,25)$. Alternatively, this could also be the result of a change in the rate at which the various DI RNA molecules replicated. In soilborne wheat mosaic furovirus, higher temperatures increased the formation of shortened forms of RNA 2 (6), consequently showing an effect of temperature that was opposite to our observation. The importance of temperature on DI RNA generation was confirmed on TSWV, though its actual effect in the mechanism of RNA deletion remains unknown.

The formation and accumulation of DI RNAs is probably regulated by numerous factors that depend on the virus itself, the host, and the interaction between the virus and the host given a specific environmental condition. DI RNAs of CNV generated in Nicotiana species were effectively filtered out when this isolate was inoculated to cucumber plants (5), suggesting a strong influence of the host in the accumulation of DI RNAs. Our studies revealed a different type of effect of host from E. sonchifolia plants. The replication of DI RNAs was supported in E. sonchifolia plants when they were present in the inoculum (data not shown), although new DI RNAs could not accumulate in these plants under all conditions tested. The failure of this species to support the accumulation and generation of DI RNAs cannot be explained by a lower virus concentration in the inocula, as the used inocula were adjusted to provide comparable virus concentrations to those used for the other plants. Our results showed that E. sonchifolia is potentially a useful host to maintain isolates of TSWV free of DI RNAs.

In addition to the effects of temperature and host, high virus concentrations were also found to favor the formation of TSWV DI RNAs. The use of inocula prepared from extracts diluted 50 times, or less, resulted in the formation of DI RNAs, whereas none were found when 1,000 times diluted extracts were incubated at $23^{\circ} \mathrm{C}$. These results confirmed previous studies showing that DI RNAs were readily generated when serially inoculated with virus inocula in high concentrations $(4,14,22)$. The use of high virus concentrations increases the likelihood of coinoculating the initially generated DI RNA with helper genomic RNAs (24).
After 15 serial inoculations, several of the lines were subjected to Northern blot analysis for detection of defective RNA molecules originating from $\mathrm{M}$ and S RNAs. However, no such defective RNA molecules were found (data not shown). This observation confirmed earlier reports $(22,23)$ that TSWV DI RNAs are only generated from the L RNA.

This study had a primary aim to determine some of the factors that could affect the generation of TSWV DI RNAs upon inoculation of plants with TSWV. The results showed that to secure or maintain the original wild-type form of a TSWV isolate plants have to be inoculated with a highly diluted plant extract, plants have to be grown at higher temperatures, E. sonchifolia has to be used as the maintenance host, and, most importantly, the TSWV isolate must not be passaged serially frequently. Instead of avoiding the formation of DI RNA, omission of these procedures leads to the production of a large range of different DI RNAs that, in turn, will enable us to study several aspects of viral replication, packaging, and evolution.

\section{ACKNOWLEDGMENTS}

A. K. Inoue-Nagata is a doctoral student of University of Brasília (Brazil) and is supported by a fellowship from the National Research Council of Brazil (CNPq). We thank F. van Poelwijk, C. Meurs, M. Prins, and R. de O. Resende for helpful discussions.

\section{LITERATURE CITED}

1. Bailey, J. M., and Davidson, N. 1976. Methylmercury as a reversible denaturing agent for agarose gel electrophoresis. Anal. Biochem. 70:75-85.

2. Barret, A. D. T., and Dimmock, N. J. 1986. Defective interfering viruses and infections of animals. Curr. Top. Microbiol. Immunol. 128:55-84.

3. Burgyan, J., Grieco, F., and Russo, M. 1989. A defective interfering RNA molecule in cymbidium ringspot virus infections. J. Gen. Virol. 70:235-239.

4. Burgyan, J., Rubino, L., and Russo, M. 1991. De novo generation of cymbidium ringspot virus defective interfering RNA. J. Gen. Virol. 72:505-509.

5. Chang, Y. C., Borja, M., Scholthof, H. B., Jackson, A. O., and Morris, T. J. 1995. Host effects and sequences essential for accumulation of defective interfering RNAs of cucumber necrosis and tomato bushy stunt tombusviruses. Virology 210:41-53.

6. Chen, J., MacFarlane, S. A., and Wilson, T. M. A. 1995. Effect of cultivation temperature on the spontaneous development of deletions in soilborne wheat mosaic furovirus RNA 2. Phytopathology 85:299-306.

7. de Ávila, A. C., de Haan, P., Smeets, M. L. L., Resende, R. de O., Kormelink, R., Kitajima, E. W., Goldbach, R. W., and Peters, D. 1993. Distinct levels of relationships between tospovirus isolates. Arch. Virol. 128:211-227.

8. de Haan, P., Kormelink, R., Resende, R. de O., van Poelwijk, F., Peters, D., and Goldbach, R. 1991. Tomato spotted wilt virus L RNA encodes a putative RNA polymerase. J. Gen. Virol. 71:2207-2216.

9. de Haan, P., Wagemakers, L., Peters, D., and Goldbach, R. W. 1990. The S RNA segment of tomato spotted wilt virus has an ambisense character. J. Gen. Virol. 71:1001-1007.

10. de Vries, S. C., Springer, J., and Wessels, J. G. H. 1982. Diversity of abundant mRNA sequences and patterns of protein synthesis in etiolated and greened pea seedlings. Planta 156:129-135.

11. Hillman, B. I., Carrington, J. C., and Morris, T. J. 1987. A defective interfering RNA that contains a mosaic of a plant virus genome. Cell 51:427-433.

12. Huang, A. S., and Baltimore, D. 1970. Defective viral particles and viral disease processes. Nature 226:325-327.

13. Huang, A. S., and Baltimore, D. 1977. Defective interfering animal viruses. Pages 73-106 in: Comprehensive Virology, Vol. 10. H. FrankelConrat and R. R. Wagner, eds. Plenum Press, New York.

14. Knorr, D. A., Mullin, H., Hearne, P. Q., and Morris, T. J. 1991. De novo generation of defective interfering RNAs of tomato bushy stunt virus by high multiplicity passage. Virology 181:193-202.

15. Kormelink, R., de Haan, P., Meurs, C., Peters, D., and Goldbach, R. 1992. The nucleotide sequence of the M segment of tomato spotted wilt virus, a bunyavirus with two ambisense RNA segments. J. Gen. Virol. 73:2795-2804.

16. Kormelink, R., de Haan, P., Peters, D., and Goldbach, R. 1992 Viral RNA synthesis in tomato spotted wilt-infected Nicotiana rustica plants. J. Gen. Virol. 73:687-693.

17. Lai, M. M. C. 1992. RNA recombination in animal and plant viruses. Microbiol. Rev. 56:61-79. 
18. Li, X. H., Heaton, L. A., Morris, T. J., and Simon, A. E. 1989. Turnip crinkle virus defective interfering RNAs intensify viral symptoms and are generated de novo. Proc. Natl. Acad. Sci. U.S.A. 86:9173-9177.

19. Logemann, J., Schell, J., and Willmitzer, L. 1987. Improved method for the isolation of RNA from plant tissues. Anal. Biochem. 163:16-20.

20. Perrault, J. 1981. Origin and replication of defective interfering particles. Curr. Top. Microbiol. Immunol. 93:151-207.

21. Pogany, J., Romero, J., Huang, Q., Sgro, J.-Y., Shang, H., and Bujarski, J. J. 1995. De novo generation of defective interfering-like RNAs in broadbean mottle bromovirus. Virology 212:574-586.

22. Resende, R. de O., de Haan, P., de Ávila, A. C., Kitajima, E. W., Kormelink, R., Goldbach, R., and Peters, D. 1991. Generation of envelope and defective interfering RNA mutants of tomato spotted wilt virus by mechanical passage. J. Gen. Virol. 72:2375-2383.

23. Resende, R. de O., de Haan, P., van de Vossen, E., de Ávila, A. C., Goldbach, R., and Peters, D. 1992. Defective interfering L RNA segments of tomato spotted wilt virus retain both genome termini and have extensive internal deletions. J. Gen. Virol. 73:2509-2516.

24. Rochon, D. M. 1991. Rapid de novo generation of defective interfering RNA by cucumber necrosis virus mutants that do not express the 20-kDa nonstructural protein. Proc. Natl. Acad. Sci. U.S.A. 88:11153-11157.

25. Roux, L., Simon, A. E., and Holland, J. J. 1991. Effects of defective interfering viruses on virus replication and pathogenesis in vitro and in vivo. Adv. Virus Res. 40:181-211.

26. Schlesinger, S. 1988. The generation and amplification of defective interfering RNAs. Pages 167-185 in: RNA Genetics, Vol. 2. E. Domingo, J. J. Holland, and P. Ahlquist, eds. CRC Press, Boca Raton, FL.

27. Shirako, Y., and Brakke, M. K. 1984. Spontaneous deletion of soil-borne wheat mosaic virus RNA II. J. Gen. Virol. 65:855-858.

28. van Poelwijk, F., Boye, K., Oosterling, R., Peters, D., and Goldbach, R. W. 1993. Detection of the L protein of tomato spotted wilt virus. Virology 197:468-470.

29. von Magnus, P. 1954. Incomplete forms of influenza virus. Adv. Virus Res. 2:59-79. 